\title{
Could Eremotherium laurillardi (Lund, 1842) (Megatheriidae, Xenarthra) be an omnivore species?
}

\author{
Poderia Eremotherium laurillardi (Lund, 1842) (Megatheriidae, Xenarthra) ser uma espécie onívora?
}

\section{Mário André Trindade Dantas ${ }^{1}$ (), Érica Cavalcante Omena² (), Jorge Luiz Lopes da Silva ${ }^{3}$ (1) \& Alcides Sial ${ }^{2}$}

'Laboratório de Ecologia e Geociências, Instituto Multidisciplinar em Saúde, Universidade Federal da Bahia - Campus Anísio Teixeira, Vitória da Conquista, BA, Brazil

${ }^{2}$ Programa de Pós-Graduação em Geociências, Universidade Federal de Pernambuco, Recife, PE, Brazil

${ }^{3}$ Departamento de Paleontologia, Museu de História Natural, Universidade Federal de Alagoas, Maceió, AL, Brazil

E-mails: matdantas@yahoo.com.br; erica.omena@gmail.com; jluizlopess@gmail.com; sial@ufpe.br

\section{Resumo}

Apresentamos valores isotópicos de carbono $\left(\delta^{13} \mathrm{C}_{\text {collagen }}=-10.1 \%\right.$ e nitrogênio $\left(\delta^{15} \mathrm{~N}=6.8 \%\right.$ ) para Eremotherium laurillardi (Megatheriidae, Xenarthra) do Pleistoceno final de Brejo da Madre de Deus, Pernambuco (Brasil) e discutimos a possibilidade de uma dieta onívora para esta espécie. Apesar de pontual, nosso dado reforça a inferência de uma dieta herbívora para esta espécie.

Palavras-chave: Quaternário; Isotópos de carbono e nitrogênio; Megatheriidae

\section{Abstract}

We present carbon $\left(\delta^{13} \mathrm{C}_{\text {collagen }}=-10.1 \%\right.$ ) and nitrogen $\left(\delta^{15} \mathrm{~N}=6.8 \%\right.$ ) stable isotopes data for Eremotherium laurillardi (Megatheriidae, Xenarthra) from the late Pleistocene of Brejo da Madre de Deus, Pernambuco (Brazil) and discuss the possibility of an omnivore diet for the species. Our data, although ponctual, reinforce the inferences that E. laurillardi was a herbivore species.

Keywords: Quaternary; Carbon and nitrogen isotopes; Megatheriidae

\section{Introduction}

Based on carbon $\left(\delta^{13} \mathrm{C}_{\text {bioapatite }}\right)$ and oxygen $\left(\delta^{18} \mathrm{O}\right)$ stable isotope data, and stereomicrowear analysis of fossils from the late PLeistocene of Brazilian Intertropical Region - BIR, Eremotherium laurillardi (Lund, 1842) is recognized as a generalist species, with a wide niche breadth $\left(B_{\mathrm{A}}=\right.$ $0.77 \pm 0.25)$, being able to live in several habitats, since low-density forests to open savanna habitats, feeding on fruits, leaves and $\mathrm{C}_{4}$ grasses (Dantas et al., 2017, 2020; Oliveira et al., 2020).

Megatherium americanum Cuvier, 1796 is also considered a herbivore species (e.g. Bocherens et al. (2016; 2017). Nevertheless, Fariña (1996) suggested that
M. americanum could be an omnivore species, and as $E$. laurillardi is a sister taxon (Gaudin, 2004), this doubt could be extended to it as well.

Bocherens et al. $(2016 ; 2017)$ presented carbon $\left(\delta^{13} \mathrm{C}_{\text {collagen }}\right)$ and nitrogen isotopic data for M. americanum, which suggest that it indeed was a herbivore species, however, in fact, the combined use of both carbon and nitrogen isotopes that had never been analyzed for $E$. laurillardi ground sloth.

Thus, the main objective of this study is present carbon $\left(\delta^{13} \mathrm{C}_{\text {collagen }}\right)$ and nitrogen $\left(\delta^{15} \mathrm{~N}\right)$ isotopic data for an adult individual of $E$. laurillardi from Brejo da Madre de Deus, Pernambuco and discuss if it had a herbivore or an omnivore diet. 


\section{Materials and Methods}

\subsection{Isotopic Analysis}

The sample 6219, a tooth (dentine) from an adult individual of Eremotherium laurillardi from Brejo da Madre de Deus, Pernambuco was used to isotopic analysis. The stable isotope analyzes were performed at NEG-LABISE in "Centro de Tecnologia e Geociências" of Universidade Federal de Pernambuco (Recife, Pernambuco, Brazil).

For the analysis of $\delta^{13} \mathrm{C}_{\text {collagen }}$ and $\delta^{15} \mathrm{~N}$, the samples were subjected to pre-treatment for collagen extraction. The pulverized samples were demineralized through the reaction with hydrochloric acid $(\mathrm{HCl})$ at a concentration of $1 \mathrm{M}$ for 20 minutes at room temperature. The residue was washed with deionized water and centrifuged five times until the acid residue was completely removed. Then, the residue was treated with $\mathrm{NaOH}$ at a concentration of $0.125 \mathrm{M}$ for twenty hours at room temperature, to eliminate other organic residues and humic acids, and posteriorly, the sample was washed with deionized water and centrifuged five times until they were neutralized (Bocherens et al., 1994; Koch \& Fogel, 1997; Sealy et al., 2014).

After pre-treatment, approximately $700 \mu \mathrm{g}$ of each sample was weighed and packed in specific capsules for analysis of $\delta^{15} \mathrm{~N}$ and $\delta^{13} \mathrm{C}_{\text {organic }}$ in COSTECH (elemental combustion furnace) coupled to a Delta V Advantage mass spectrometer.

The reliability of the isotopic signatures of the collagen extracts was addressed using their chemical composition. Only extracts with $\% \mathrm{C}, \% \mathrm{~N}$, and $\mathrm{C} / \mathrm{N}$ similar to those of collagen extracted from fresh bone should be considered reliable for isotopic measurements. Several studies have shown that collagen with atomic $\mathrm{C} / \mathrm{N}$ ratios lower than 2.9 or higher than 3.6 are altered or contaminated, and should be discarded (DeNiro, 1985; Ambrose, 1990).

All results are reported using delta notation, $\delta=$ [(Rsample/Rstandard - 1)*1000] (Coplen, 1994). The reference for carbon $(\mathrm{R}=13 \mathrm{C} / 12 \mathrm{C})$ isotope values are in $\mathrm{V}$-PDB, while for nitrogen $(\mathrm{R}=15 \mathrm{~N} / 14 \mathrm{~N})$ are in atmospheric nitrogen (AIR).

\subsection{Isotopic Diet Interpretation Using $\delta^{15} \mathrm{~N}$ and $\delta^{13} C$ Values}

Nitrogen isotopes could help us to differentiate between grazers and browsers, high values of nitrogen are indicative of a grazer diet, while lower values are indicative of a browser diet (Bocherens \& Drucker, 2013).
The interpretation of carbon isotopic values for medium-to large-bodied herbivorous mammals is generally made based on the known average for $\mathrm{C}_{3}$ plants $\left(\mu \delta^{13} \mathrm{C}=\right.$ $-27 \pm 3 \%$ ), $\mathrm{C}_{4}$ plants $\left(\mu \delta^{13} \mathrm{C}=-13 \pm 2 \%\right.$ ) and CAM plants (intermediate values between $\delta^{13} \mathrm{C}, \mathrm{C}_{3}$ and $\mathrm{C}_{4}$ plants). $\mathrm{C}_{3}$ photosynthetic pathways include arbustive and/or arboreal plants, as also grasses that occur more in high altitudes $(>3,000 \mathrm{~m})$ and high latitudes $\left(>35^{\circ} \mathrm{S}\right)$ (MacFadden, 2005 and references therein). $\mathrm{C}_{4}$ photosynthetic pathways in the intertropical region include mainly grasses and other herbaceous plants (e.g. Dantas et al., 2017).

We use the typical isotopic enrichment of collagen in mammal tissues of $+5 \%$ (Bocherens \& Drucker, 2013). We adapted the expected $\delta^{13} \mathrm{C}$ values in different habitats of South America from bioapatite (Domingo et al., 2012) to collagen. Thus, values between $-31 \%$ to $-25 \%$ represents closed-canopy forest; $-25 \%$ to $-20 \%$ represents lowdensity forest; $-20 \%$ to $-17 \%$, arboreal savanna; $-17 \%$ to $-12 \%$, arboreal to open savanna; and, $-12 \%$ o to $-4 \%$, open savanna (Figure 1).

Food resources proportion of E. laurillardi could be suggested using a single isotope mathematical mixing model (Phillips, 2012) for food types: $\mathrm{C}_{3}$ and $\mathrm{C}_{4}$ plants (-22\%o and $-8 \%$, respectively), to be applied in equations (1) in Excel (Microsoft Corporation, Redmond, Washington) through Solver supplement (presuming non-negative values):

$$
\begin{gathered}
\delta^{13} \mathrm{C}_{\text {mix }}=\delta^{13} \mathrm{C}_{1} f_{1}+\delta^{13} \mathrm{C}_{2} f_{2} \\
1=f_{1}+f_{2}
\end{gathered}
$$

\subsection{Ecological Measurements}

To estimate ecological measurements, we calculate isotope niche breadth $(B)$ using Levins (1968) measure (2), where $p_{\mathrm{i}}$ is the relative proportion of individuals in isotope bin $i$. This measure was then standardized $\left(B_{\mathrm{A}}\right)$ from 0 to 1 following equation (3), where $n$ is total number of isotope bins available. Values lower or equal to 0.5 suggests a specialist, and above 0.5 , a generalist.

$$
B=\frac{1}{\sum p_{i}^{2}}
$$

$$
B_{A}=\frac{B-1}{N-1}
$$



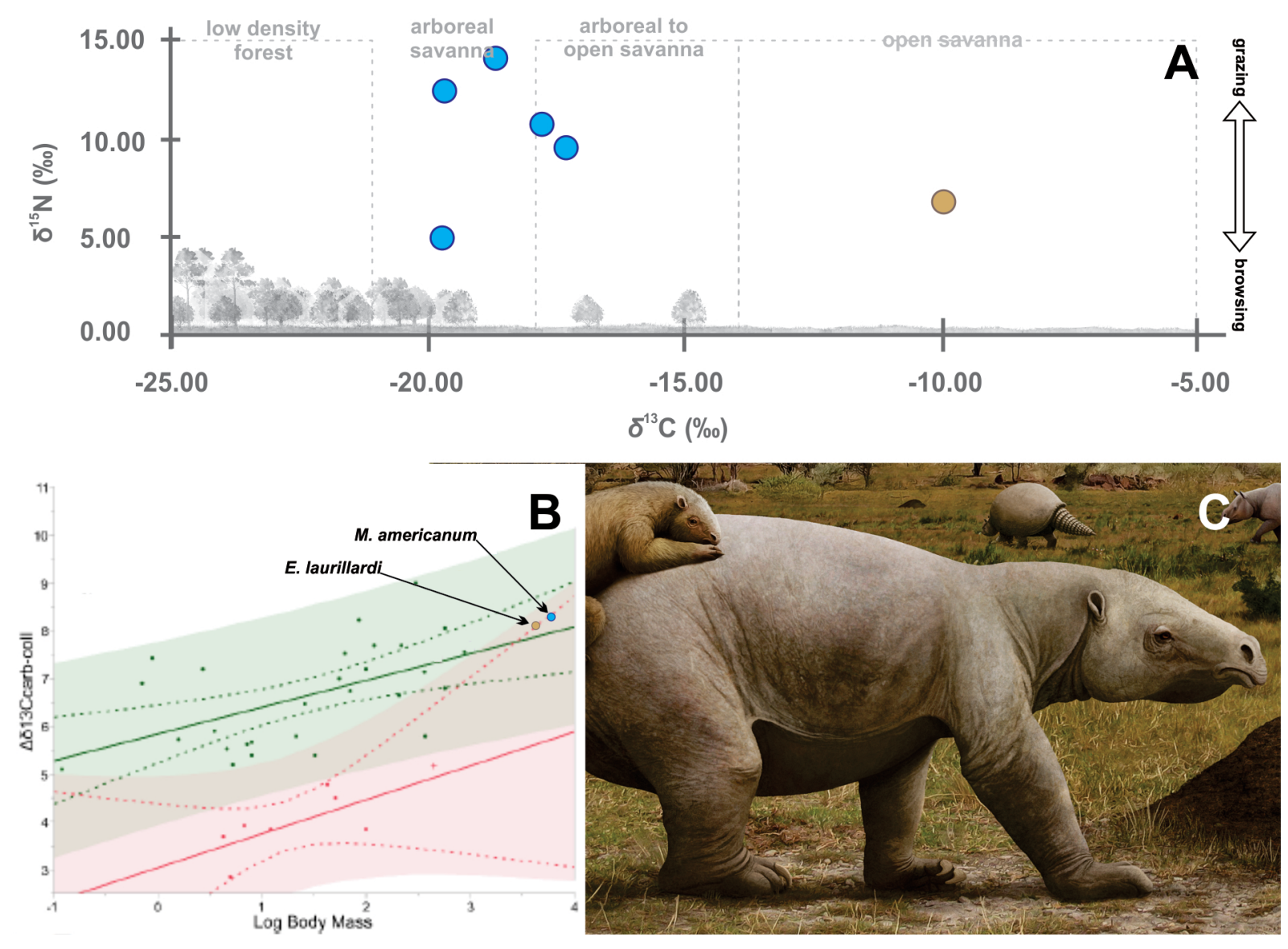

Figure $1 \mathrm{~A}$. Carbon $\left(\delta^{13} \mathrm{C}_{\text {collagen }}\right.$ ) and Nitrogen $\left(\delta^{15} \mathrm{~N}\right)$ isotopic values for Megatherium americanum (blue dots) and Eremotherium laurillardi (brown dot); B. Regressions of log body mass (modified from Fariña \& Varela, 2018) and $\Delta \delta^{13} \mathrm{C}_{\text {collagen }}$ for $M$. americanum (blue dot) and E. laurillardi (brown dot), Carnivores (light symbols), herbivores (dark symbols). Regression lines (solid) include confidence intervals (dotted) and prediction intervals (shaded area). C. E. laurillardi reconstitution (Image: Julio Lacerda, 2020).

\section{Results and Discussion}

The Eremotherium laurillardi (sample 6219) from Brejo da Madre de Deus, Pernambuco presented a C/N ratio of 3.2 and $3.4 \% \mathrm{~N}$, allowing us to suggest good preservation of collagen in organic carbon as mentioned in previous studies (e.g., DeNiro, 1985; Ambrose, 1990; Bocherens et al., 1994; 2016).

The carbon isotopic value $\left(\delta^{13} \mathrm{C}_{\text {collagen }}\right)$ was $-10.1 \%$ (Table 1), which represents a diet composed of $86 \%$ of $\mathrm{C}_{4}$ grasses, being a specialist adult individual $\left(B_{\mathrm{A}}=0.31\right)$ that possibly could have lived in open savanna habitats (Figure $1 \mathrm{~A}$ and $\mathrm{C}$ ). Isotopic data in collagen from BIR fossils are rare, due to diagenetic process which promoted the loss of collagen. The only previous isotopic data for E. laurillardi made in collagen with association of radiocarbon dating was presented by Drefahl (2010). The study showed that the individual would have lived at 18,730-19,280 Cal yr BP in Quinjingue, Bahia and had a generalist $\operatorname{diet}\left(\delta^{13} \mathrm{C}_{\text {collagen }}\right.$ $=-18.2 \%)$ composed mainly of $\mathrm{C}_{3}$ plants $\left(p_{\mathrm{i}} \mathrm{C}_{3}=71 \%\right.$; $\left.B_{\mathrm{A}}=0.70\right)$ from arboreal savanna habitats.

Based on radiocarbon datings and carbon isotopic data acquired from hydroxyapatite we know that $E$. laurillardi lived in BIR, at least, between 34 to $10 \mathrm{Cal} \mathrm{yr}$ BP (Dantas et al., 2017; Oliveira et al., 2020), and it was a generalist species, with a wide niche breadth $\left(B_{\mathrm{A}}=0.77 \pm\right.$ $0.25)$. E. laurillardi possibly could have lived in several habitats, as low-density forests to open savanna habitats, feeding on fruits, leaves $\left(p_{\mathrm{i}} \mathrm{C}_{3}=52 \%\right)$ and $\mathrm{C}_{4}$ grasses $\left(p_{\mathrm{i}} \mathrm{C}_{4}=\right.$ $48 \%$ ) (Dantas et al., 2017). Thus, these two discordant values found in collagen, is in fact expected for this species. 
The $\delta^{15} \mathrm{~N}$ value of $E$. laurillardi was $6.8 \%$, which is expected for a grazer, since $\mathrm{C}_{4}$ plants can have higher values of $\delta^{15} \mathrm{~N}$ (e.g. Bocherens \& Drucker, 2013). Whether E. laurillardi was an omnivore species, it could feed prey taxa with $\delta^{15} \mathrm{~N}$ values of $3.8 \%$ or $1.8 \%$, considering the most common enrichments of trophic niche $+3 \%$ and +5\%o, respectively (Bocherens \& Drucker, 2013). However, these $\delta^{15} \mathrm{~N}$ values could represent browser taxa, that would have lived in closed habitats, as low-density forests or arboreal savanna, thus in a different habitat expected for this E. laurillardi individual according to its carbon isotope value. Therefore, the proposition made by Fariña (1996) for Megatherium americanum suggesting that it could be an omnivore species, could not be attributed for E. laurillardi.

Table 1 Carbon and nitrogen isotopic data, proportion of food resources, and niche breadth for $E$. laurillardi and $M$. americanum. Labels. ${ }^{(1)}$ Our data; ${ }^{(2)}$ Drefahl (2010); ${ }^{(3)}$ Bocherens et al. (2016, and references therein)

\begin{tabular}{|c|c|c|c|c|c|}
\hline \multirow{2}{*}{ Taxa } & \multirow{2}{*}{$\delta^{13} \mathrm{C}$} & \multirow{2}{*}{$\delta^{15} \mathrm{~N}$} & \multicolumn{2}{|c|}{$\mathbf{p}_{\mathrm{i}}$} & \multirow{2}{*}{$\mathrm{B}_{\mathrm{A}}$} \\
\hline & & & $\mathbf{C}_{3}$ & $\mathrm{C}_{4}$ & \\
\hline \multirow[t]{2}{*}{ E. laurillardi } & $-10.1^{(1)}$ & $6.8^{(1)}$ & 0.14 & 0.86 & 0.31 \\
\hline & $-18.2^{(2)}$ & - & 0.71 & 0.29 & 0.70 \\
\hline \multirow[t]{5}{*}{ M. americanum } & $-18.7^{(3)}$ & $14.0^{(3)}$ & 0.76 & 0.24 & 0.57 \\
\hline & $-19.7^{(3)}$ & $12.4^{(3)}$ & 0.84 & 0.16 & 0.37 \\
\hline & $-17.3^{(3)}$ & $9.5^{(3)}$ & 0.66 & 0.34 & 0.81 \\
\hline & $-17.8^{(3)}$ & $10.7^{(3)}$ & 0.70 & 0.30 & 0.72 \\
\hline & $-19.7^{(3)}$ & $5.2^{(3)}$ & 0.84 & 0.16 & 0.37 \\
\hline
\end{tabular}

Bocherens et al. (2016, and references therein) presented five isotopic data of carbon $\left(\delta^{13} \mathrm{C}_{\text {collagen }}\right)$ and nitrogen $\left(\delta^{15} \mathrm{~N}\right)$ for $M$. americanum, and inferred that this species could feed almost $\sim 76 \%$ of $\mathrm{C}_{3}$ plants, whose grasses would be the most important resources foraged, as the nitrogen values were high $\left(\mu \delta^{15} \mathrm{~N}=10.4 \pm 3.3 \%\right.$ ). Bocherens et al. (2016) also showed that the $\delta^{15} \mathrm{~N}$ from the saber-tooth Smilodon populator $\left(\mu \delta^{15} \mathrm{~N}=13.4 \pm 1.4 \%\right.$ ) was higher and statistically different from those of $M$. americanum, reinforcing the inferences about a herbivorous diet for this ground sloth

Nevertheless, Fariña \& Varella (2018) point that Bocherens et al. (2017) did not take into account the body mass of M. americanum, and using a log of body mass proposed by Smith et al. (2004) and carbon isotopic data (acquired in collagen) for several mammals reinforce that M. americanum could be an omnivore, as it appears in the limit of carnivorans (Figure 1B).

Using the two available carbon isotopic data for Eremotherium laurillardi $\left(\Delta \delta^{13} \mathrm{C}_{\text {collagen }}=8.1 \%\right.$ ) and the body mass $(3,400 \mathrm{~kg}$ ) proposed by Dantas (2019), we include it in the regression (Figure 1B). We noted that E. laurillardi falls in the carnivorans limit, as M. americanum (Figure 1B), which shows that use only carbon isotopic data is not the best tool, only nitrogen isotopes could help to infer if these species presented a herbivorous or an omnivorous diet.

\section{Final Remarks}

In the present manuscript, although with a punctual carbon $\left(\delta^{13} \mathrm{C}_{\text {collagen }}=-10.1 \%\right)$ and nitrogen $\left(\delta^{15} \mathrm{~N}=6.8 \%\right.$ ) isotopic data, we suggest that $E$. laurillardi was a herbivore species and that the proposition of an omnivore diet for M. americanum and, consequently, for E. laurillardi could be mistaken.

\section{Acknowledgement}

To CAPES for author masters' scholarship; To $\mathrm{CNPq}$ by research fellowship for author $(\mathrm{PQ} / \mathrm{CNPq}$ 311003/2019-2).

\section{References}

Ambrose, S.H. 1990. Preparation and characterization of bone and tooth collagen for isotopic analysis. Journal of Archaeological Science, 17: 431-451.

Bocherens, H. \& Drucker, D.G. 2013. Terrestrial Teeth and Bones. In: Elias, S.A. (Ed.). The Encyclopedia of Quaternary Science. Amsterdam: Elsevier. 304-314p.

Bocherens, H.; Cotte, M.; Bonini, R.; Scian, D.; Straccia, P.; Soibelzon, L. \& Prevosti, F.J. 2016. Paleobiology of sabertooth cat Smilodon populator in the Pampean Region (Buenos Aires Province, Argentina) around the Last Glacial Maximum: Insights from carbon and nitrogen stable isotopes in bone collagen. 
Palaeogeography, Palaeoclimatology, Palaeoecology, 449: 463-474. doi: 10.1016/j.palaeo.2016.02.017

Bocherens, H.; Cotte, M.; Bonini, R.A.; Straccia, P.; Scian, D.; Soibelzon, L. \& Prevosti, F.J. 2017. Isotopic insight on paleodiet of extinct Pleistocene megafaunal Xenarthrans from Argentina. Gondwana Research, 48: 7-14. doi: 10.1016/j. gr.2017.04.003.

Bocherens, H.; Fizet, M. \& Mariotti, A. 1994. Diet, physiology and ecology of fossil mammals as inferred from stable carbon and nitrogen isotope biogeochemistry: Implications for Pleistocene bears. Palaeogeography, Palaeoclimatology, Palaeoecology, 107(3-4): 213-225.

Coplen, T.B. 1994. Reporting of stable hydrogen, carbon, and oxygen isotopic abundances. Pure and Applied Chemistry, 66: 273-276.

Dantas, M.A.T. 2019. Atualizando a estimativa da massa corporal da megafauna do Pleistoceno Final da Região Intertropical Brasileira. In: Boletim de Resumos, Congresso Brasileiro de Paleontologia, Uberlândia, Minas Gerais.

Dantas, M.A.T.; Cherkinsky, A.; Bocherens, H.; Drefahl, M.; Bernardes, C. \& França, L.M., 2017. Isotopic paleoecology of the Pleistocene megamammals from the Brazilian Intertropical Region: Feeding ecology $(\delta 13 \mathrm{C})$, niche breadth and overlap. Quaternary Science Reviews, 170: 152-163. doi: 10.1016/j. quascirev.2017.06.030.

Dantas, M.A.T.; Cherkinsky, A.; Lessa, C.M.B.; Santos, L.V.; Cozzuol, M.A.; Omena, É.C.; Silva, J.L.L.; Sial, A.N. \& Bocherens, H. 2020. Isotopic paleoecology $(\delta 13 \mathrm{C}, \delta 18 \mathrm{O})$ of Late Quaternary megafauna from Brazilian Intertropical Region. Revista Brasileira de Paleontologia, 23(2): 138-152. doi: 10.4072/rbp.2020.2.05

DeNiro, M.J. 1985. Postmortem preservation and alteration of invivo bone collagen isotope ratios in relation to palaeodietary reconstruction. Nature, 317: 806-809.

Domingo L, Prado JL, Alberdi MT. 2012. The effect of paleoecology and paleobiogeography on stable isotopes of Quaternary mammals from South America. Quaternary Science Reviews, 55: 103-113.doi: 10.1016/j.quascirev.2012.08.017

Drefahl, M. 2010. Implicações paleoambientais preliminares da análise de $\delta 13 \mathrm{C}$ em osso de paleomastofauna procedente de Quijingue, Bahia. In: Boletim de Resumos, Simpósio Brasileiro de Paleobotânica e Palinologia, Salvador, ALPP, Bahia, p. 239.
Fariña, R.A. 1996. Trophic relationships among Lujanian mammals. Evolutionary Theory, 11: 125-134.

Fariña, R.A. \& Varela, L. 2018. Comment on "Isotopic insight on paleodiet of extinct Pleistocene megafaunal Xenarthrans from Argentina" by H. Bocherens, M. Cotte, R. A. Bonini, P. Straccia, D. Scian, L. Soibelzon and F. J. Prevosti, Gondwana Research, Volume 48, Issue 1, Pages 7-14. Gondwana Research, 58: 241-242. doi: 10.1016/j.gr.2018.03.004

Gaudin, T.J. 2004. Philogenetic relationships among sloths (Mammalia, Xenarthras, Tardigrada): the craniodental evidence. Zoological Journal of the Linnean Society, 140: 255-305.

Koch, P.L. \& Fogel, M.L. 1997. The Effects of Sample Treatment and Diagenesis on the Isotopic Integrity of Carbonate in Biogenic Hydroxylapatite. p. 417-429.

Levins, R. 1968. Evolution in changing environments. New Jersey, Princeton University Press, IX $+120 p$.

MacFadden, B.J. 2005. Diet and habitat of toxodont megaherbivores (Mammalia, Notoungulata) from the late Quaternary of South and Central America. Quaternary Research, 64:113-124.

Oliveira, J.F.; Asevedo, L.; Cherkinisky, A. \& Dantas, M.A.T. 2020. Radiocarbon dating and integrative paleoecology $(\delta 13 \mathrm{C}$, stereomicrowear) of Eremotherium laurillardi (LUND, 1842) from midwest region of the Brazilian intertropical region. Journal of South American Earth Sciences, 102. 102653. doi: 10.1016/j.jsames.2020.102653

Phillips, D.L. 2012. Converting isotope values to diet composition: the use of mixing models. Journal of Mammalogy, 93(2):342352. doi: 10.1644/11-MAMM-S-158.1

Sealy, J.; Johnson, M.; Richards, M.; Nehlich, O. 2014. Comparison of two methods of extracting bone collagen for stable carbon and nitrogen isotope analysis: comparing whole bone demineralization with gelatinization and ultrafiltration. Journal of Archaeological Science, 47: 64-69.

Smith, F.A.; Brown, J.H.; Haskell, J.P.; Alroy, J.; Charnov, E.L.; Dayan, T.; Enquist, B.J.; Ernest, S.K.M.; Hadly, E.A.; Jablonski, D.; Jones, K.E.; Kaufman, D.M.; Lyons, S.K.; Marquet, P.; Maurer, B.A.; Niklas, K.; Porter, W.; Roy, K.; Tiffney, B. \& Willig, M.R. 2004. Similarity of mammalian body size across the taxonomic hierarchy and across space and time. American Naturalist, 163: 672-691.

Received: 17 July 2020

Accepted: 8 October 2020

\section{How to cite:}

Dantas, M.A.T.; Omena, É.C.; Silva, J.L.L.; \& Sial, A. 2021. Could Eremotherium laurillardi (Lund, 1842) (Megatheriidae, Xenarthra) be an omnivore species?. Anuário do Instituto de Geociências, 44: 36492. DOI 1982-3908_2021_44_36492 